UDC: 159.9 .072 .432

DOI: https://doi.org/10.24195/2414-4665-2017-1-6

\author{
Willie van Peer, \\ PhD, Ludwig Maximilian University, \\ 2, Professor-Huber-Platz, Munich, Germany, \\ Anna Chesnokova, \\ PhD (Candidate of Philological Sciences), \\ Borys Grinchenko Kyiv University, \\ 18/2, Bulvarno-Kudriavska Str., Kyiv, Ukraine,
}

Matthias Springer,

PhD, Ludwig Maximilian University,

2, Professor-Huber-Platz, Munich, Germany

\title{
DISTRESSFUL EMPATHY IN READING LITERATURE: THE CASE FOR TERROR MANAGEMENT THEORY?
}

This article investigates the extent to which predictions of Terror Management Theory also hold on reading literature. Indeed, death is ubiquitous in fiction. But does reading about it cause the same reactions as those predicted by Terror Management Theory? To answer this question, five reading experiments were carried out. The hypothesis, developed in the framework of Terror Management Theory, that direct confrontation with one's mortality strengthens both prejudices against outsiders and enhances in-group values, was tested. Contrary to initial expectations, the results did not confirm the predictions, casting a shadow over the hypothesis of distressful empathy. This raises the question whether mortality salience in literary texts is different from other such confrontations. This leads us to the question why people indulge in such distressful emotions. It will be argued that confrontation with death in literature may actually relieve the tension produced by mortality reminders. This perspective may be linked to Aristotle's notion of catharsis.

Keywords: empathy, Terror Management Theory, mortality salience, literary texts, non-fictional texts, catharsis.

'There is nothing more stimulating than a case where everything goes against you.'

(A. Conan Doyle: The Hound of the Baskervilles, 1981: 696)

1. Theoretical background.

Terror Management Theory

Terror Management Theory (henceforth - TMT) is a theory in social psychology that grew out of existential psychology, especially the writings of Becker (1973), in the wake of Kierkegaard's (1957) philosophy. The major developers of the theory, psychologists Tom Pyszczynski, Sheldon Solomon and Jeff Greenberg, argue that being conscious of our mortality (a unique human capacity) raises 'terror'. The authors hold that ' $[\mathrm{t}]$ error is (...) a uniquely human response to the threat of annihilation' (Pyszczynski et al., 2002: 8) . Such consciousness may be induced by many factors: visiting a hospital, hearing about a friend's death, walking by a cemetery, etc. Ironically, TMT is about effects death has on our lives.

The "terror" caused in our mind and feeling asks for some kind of "management". We would not be able to stand the innate fear of dying if there were no "defence mechanism" that would help humans handle it. Thus '[t]error management theory is about how humans cope, not with the imminent threat of extermination but with the awareness that such threats are ubiquitous and will all eventually succeed' (Pyszczynski et al., 2002: 8).

\subsection{Mortality salience}

Reminders of one's finality are described in TMT as mortality salience (henceforth - MS). They call for reassurance of prevailing world views and strengthen behaviour related to those world views, while at the same time repudiating anyone calling these in doubt. One consequence is an increase in prejudice and animosity against outsiders (who do not share our values). In the words of Arndt et al. (2002): '[a]cross at least seven different countries (...) more than 90 studies have found that a reminder to participants of their mortality increases such responses as positive evaluations of those who validate the participants' belief system and negative evaluations of those who threaten it (e.g., Rosenblatt et al., 1989), perceived consensus for the participants' beliefs (Pyszczynsky et al., 1996), reluctance to violate cultural norms (Greenberg et al., 1995), stereotypic thinking and preference (Schimel et al., 1999), and aggression against those who violet the cultural worldview (McGregor et al., 1998). Moreover, these effects occur in response to a number of different operationalizations to heighten death-related thought (e.g. proximity to a funeral home, subliminal death primes) and have occurred relative to a variety of control conditions' (308).

The MS hypothesis has been confirmed in more than 120 studies in 9 different countries, both in laboratory and in field studies. Yet, to the best of our knowledge, there has been no attempt of checking whether literature fiction or not - can act as a MS trigger, and this is what motivated our research. 
1.2 Empathy and mortality salience in literature

We are interested in whether MS calls forward the same or similar reactions to death through reading about it in literature. The reason might be clear: death is ubiquitous in literature. From the death of Enkidu in the Gilgamesh epic or the deaths of Patroclos and Hector in Homer's Iliad at the dawn of western literary history, or of Jocasta in Oedipus the King by Sophocles, the cruel death of Jesus, of the heroic deaths of Beowulf, of Roland in The Song of Roland, the deaths of Tristan and Isolde, of Ophelia in Hamlet and of the protagonists Romeo and Juliet, of Marlowe's Dr. Faustus, of Werther in The Sorrows of Young Werther, of Madame Bovary and Anna Karenina, of Little Nell in The Old Curiosity Shop, of the protagonists in Edgar Allan Poe or Franz Kafka, and in Thomas Mann's Death in Venice, one never has to look far or long to find death being foregrounded in literary works. Such evocations of death, in the hands of great writers, usually have a vividness and realism that may draw readers emotionally into the description. Through empathy, readers may identify themselves with the dying person, and as such, be reminded of death and the finality of their own life. Such reminders of one's own end may become particularly acute when the story is presented in the first person.

In western cultures the term 'empathy' is associated with positive values: it is generally thought good if people feel empathetic, and children are standardly brought up to take feelings of other people into consideration. But what if empathy is distressful? Literary authors are often quite adept at describing situations or events evoking extremely strong empathetic emotions. How then will such forms of distressful empathy relate to the reactions to death as described in TMT? The descriptions of death in literary texts may quite easily be considered to be some kind of MS. Indeed, they do not really differ from when we hear of a relative's death. And if they are considered as MS, will they - just as in TMT research - boost prejudices against outsiders and strengthen in-group values? With these ideas in mind, we ran a series of experiments, in which one group of readers read a text with (presumed) MS, and another one without. The experiments' methodology will be detailed in the next section.

\section{Methods}

\subsection{Study 1}

The first experiment was held in Kiev, Ukraine, in February 2014. Participants of the study were 57 students (all female, mean age 20 years), from the MA programme in English Philology at Borys Grinchenko Kyiv University. The respondents constituted two groups. Twenty-six participants in the experimental group were invited to read (as an MS text) part of the chapter 'Ilyusha' from Dostoyevsky's The Brothers Karamazov (Book X, chapter 7) in which a young boy is dying. Here is an extract from the text we used:

The doctor came out of the room again, muffled in his fur coat and with his cap on his head. His face looked almost angry and disgusted, as though he were afraid of getting dirty. He cast a cursory glance round the passage, looking sternly at Alyosha and Kolya as he did so. Alyosha waved from the door to the coachman, and the carriage that had brought the doctor drove up. The captain darted out after the doctor, and, bowing apologetically, stopped him to get the last word. The poor fellow looked utterly crushed; there was a scared look in his eyes.

"Your Excellency, your Excellency... is it possible?" he began, but could not go on and clasped his hands in despair. Yet he still gazed imploringly at the doctor, as though a word from him might still change the poor boy's fate.

The control group (31 respondents) read a specifically designed neutral text: 'A History of the Toothbrush':

A toothbrush is a device for cleaning teeth and massaging gums. As a rule, it is applied by using toothpaste.

Modern toothbrushes are diverse in shape. Their working surface consists of natural or synthetic fibres of various sizes and hardness. Electric toothbrushes are also manufactured.

Toothbrushes produced in Russia or imported into the territory of Russia must comply with the GOST 638891 standard.

Both texts were approximately of the same length (about 600-800 words) and were offered in Russian - the original of Dostoyevsky's novel. The texts were presented in an academic setting during a guest lecture of the first author.

After both groups read the texts, they were asked to indicate how much they agreed or disagreed with 10 statements listed below, which we thought would gauge the effect of MS on the group's world views:

1. It is difficult to behave naturally in the presence of someone severely handicapped.

2. I would be happy if someone in my family would marry a person from China or Japan.

3. The police found a young man red-handed while stealing an iPod. He deserves to be punished severely.

4. A family from the Caucasus moves into the apartment next door. I feel threatened by it.

5. Mentally handicapped people should generally live among normal people.

6. Fugitives from a totalitarian regime should be allowed as citizens in my country.

7. I am of the opinion that one should pay more attention to heroism in our society.

8. In comparison to other cultures I am enamoured with the way in which we live together in my country.

9. Imagine you have unexpectedly gained 200 hryvnyas [the local Ukrainian currency] last week. Because of this luck, I believe I should donate this money for charity.

10. I would really like to spend a holiday in Africa.

As may be clear from the list, some items probe nationalism $(1,7,8)$, others gauge attitudes toward outsiders $(2,4,10)$, still others with human rights $(5,6)$, 
one with ideas about law and punishment (3), and one about compassion (9). The list is intentionally heterogeneous, as we wanted to obtain some spectrum of attitudes that are considered as indicative of people's empathic reactions to MS.

A 4-point scale was used in the questionnaires so that participants were forced to make an unambiguous choice. The points of the scale were explicitly marked: 'totally agree', 'somewhat agree', 'somewhat disagree' and 'totally disagree' so that respondents were conscious of their decisions. At the end of the questionnaire, participants indicated their gender and age.

The data were collected and subsequently analysed using SPSS. Surprisingly, no significant differences were found in reaction to the two texts in answering the ten questions. An ANOVA revealed only one significant difference - that for the 'heroism' item: a score of 3.7 for the MS condition, and of 3.4 for the control condition ( $\mathrm{p}=$ .049), showing both a marginal significance and also a relatively small effect size.

Out of ten items, that is not very convincing for TMT: if TMT is right in its predictions generally, they seem NOT to hold for MS when produced through empathy in the reading of literature.

\subsection{Study 2}

A second experiment was held in Munich, Germany, in 2014 and included 74 students from Munich University (57 German native speakers, 62 female and 12 male). The same texts (Dostoyevsky's and 'The History of the Toothbrush') were used, together with a passage from Orhan Pamuk's The Museum of Innocence, it being a literary text, like Dostoyevsky's, but without any MS. All texts and the questionnaires were offered in German. After participants read the texts, they were presented with the same 10 statements about social prejudice as reported in Study 1.

The analysis yielded no significant differences between responses to the text-condition. A reliability analysis was carried out for all items, and Cronbach's alpha was at .358 , hence no data reduction could be carried out, meaning that the test items were independent of each other. We did not consider this a disadvantage, since we were not interested in a single measure of TMT. The considerations to this effect mentioned in the report on Study 1 apply equally to the present study.

A Kolmogorov-Smirnov test revealed that the data (not surprisingly) were not normally distributed; hence non-parametric tests of comparison of means had to be used. A Kruskal-Wallis and Median test was run, the results of which revealed no significant differences by text-response to none of the 10 items, therefore the nullhypothesis has to be retained. So there seems to be intercultural agreement between Ukrainian and German respondents in their mental make-up. In the current sample, there were also no significant differences between native and non-native speakers (of German). No significant differences for gender were found either. So we are facing another study in which a replication of TMT experiments ended in negative results.

\subsection{Study 3}

The third experiment was conducted in Kiev, Ukraine, in March 2015 at the same university as Study 1. Because the Dostoyevsky text used in Study 1 contained elements of social support (e.g., the dying boy's friends being with him, the doctor, the captain, the young monk Alyosha), we decided to use another text as an MS trigger, in which no such traces of social support are to be found: the final chapter of Tolstoy's The Death of Ivan Ilyich. The passage was approximately the same length as the one applied in Study 1 (631 words). We slightly manipulated the text and removed from it any remaining social elements that might have had a mitigating effect on MS (the presence of the protagonist's wife and daughter, for instance). The story is a stark and gripping description of a person dying in agony and excruciating pain, so we hypothesised that reading about the suffering of the man should raise empathy for his plight and subsequently remind respondents of their own mortality. Here is an extract from the text (presented to 19 readers in the experimental condition in Russian, its original language):

From that moment the screaming began that continued for three days, and was so terrible that one could not hear it through two closed doors without horror. At the moment he answered his wife he realized that he was lost, that there was no return, that the end had come, the very end, and his doubts were still unsolved and remained doubts. "Oh! Oh! Oh!" he cried in various intonations. He had begun by screaming "I won't!" and continued screaming on the letter " $O$ ".

The text was again contrasted with 'The History of the Toothbrush', read by 22 control group respondents.

In our communication with the TMT authors, they pointed out that the respondents' general tolerance and openness to the world might also influence the results (Pyszczynski et al., 2002: 82-83). Hence in designing Study 3 , we decided to build in a control for such attitudes of tolerance and open-mindedness. To this end, before reading the texts, participants filled out their answers to statements probing their general cultural openness / tolerance by using 6 items as a pre-measure:

1. What this country needs most, more than laws and political programs, is a few courageous, tireless, devoted leaders in whom the people can put their faith.

2. Nowadays when so many different kinds of people move around and mix together so much, a person has to protect himself especially carefully against catching an infection or disease from them.

3. Homosexual men and women should have the same rights as heterosexual people.

4. I am bothered by people who go about in traditional, non-European clothes, like headscarves or djellaba's.

5. Other cultures fascinate me.

6. Claims that current levels of pollution are changing earth's climate are exaggerated. 
As will be clear, items 3 and 5 are indicative of general tolerance while items $1,2,4$, and 6 indicate the opposite. In the analysis, all items were redirected, of course, so that all answers point in the same direction. In search for more subtle reactions, the scale we used this time was extended to 10 -points.

After the pre-test, both the experimental and control groups read the two texts and were invited to express their agreement or disagreement with 10 statements that were meant to gauge their mood and probe their attitudes towards outsiders, since, according to TMT, such attitudes influence the way in which people react to MS. The statements were the same ones that had been used in Studies 1 and 2 described before.

In order to make participants' reactions unconscious, according to TMT, we had a delay between reading and responding. Thus, the participants of the study were distracted by another experiment, on a totally unrelated issue, namely the perception of beauty in a poem, which lasted for about 10 minutes. After that, participants filled out their reactions to the 10 post-test items.

When the data were collected, we analysed participants' responses according to their general 'tolerance' level in a split median test, using an ANOVA to measure significance levels. Out of the 6 pre-questions combined with the 10 post-questions, only 2 (out of 60 !) yielded significant results (the pre-question 'heroism needed' had an effect on 'handicapped people', $p=.004$; and the item 'other cultures' influenced 'handicapped people', $\mathrm{p}=.002$ ). We are inclined to completely neglect these results in view of the extremely low number of significances: $2 / 60$. It is not particularly convincing as to the difference between reading the experimental text (Tolstoy) and the control text ('The History of the Toothbrush').

It is quite conceivable, though, that we are hitting ceiling / bottom effects. For instance, for pre-question number 4 ('I am bothered by people who go about in traditional, non-European clothes, like headscarves or djellaba's') the median value is 1 on a scale of 10 , meaning that nobody in the sample was troubled at all by traditional clothing of foreigners.

A reliability analysis for the first 6 questions was carried out, but Cronbach's alpha turned out to be low again (in the range of .30). We nevertheless tried to conflate the 6 items, did a medium split for them and then ran the analysis again, but there was no effect.

Again the conclusion must be clear: although the Tolstoy text is much starker in its unabashed description of the heart-rending suffering and agony of the protagonist, presumably calling forward some kind of empathy in the reader, no effects of this text (in comparison with the control one) were registered. Moreover, the pre-test questions gauging general tolerance and openness did not indicate any influence of the items on the results of the post-reading test. In any case, the usual predictions derived from TMT did not apply to reading about death, even in the gripping style of one of the greatest authors of all times.

\subsection{Study 4}

Because the experimental texts used in Studies 1, 2 and 3 were fictional, we decided to carry out a study in which a real life narrative of death would be used. This was administered in March 2015 in Kiev. We opted for a narrative of approximately the same length (655 words), taken from a recent newspaper in Ukraine telling of killings in the civil war in the Donbass region in the East of the country - a text very recognisable to readers as being non-fictive recent history. The text was presented to 34 respondents $(91.2 \%$ female, mean age 19.7), all students of EFL at the same university, comparable to the samples in Studies 1 and 3, in its original, in Russian, and was manipulated in the sense that any political implications were deleted from the story, in order to avoid readers' identification with any political affiliation during and after their reading. The text is simply a gruesome account of a young boy's deathly sufferings. Here is an extract:

"And so I've heard my son crying", Eduard is recollecting. "I ran up to him to see that his ... leg had been torn apart. It was there, next to him, hanging on tendons. "Daddy, what is it?!" Dima was crying, terrified. "Are you sure she is breathing?" "Who is 'she'?" I asked with just my lips. "Lera!" my son shouted. "She is here!" I did not see her at first. Dima was lying on Lera, covering her with his body. My daughter was conscious, but terribly frightened.

"What was it?" the daughter asked. Dima was trying to explain it to her, while bleeding himself. Every second counted.

I held my son in my arms and carefully took his torn little leg. "Help! In the name of Christ, please save my son!" I was crying so loudly that I think everybody in the street could hear me. Luckily, my brother was nearby, so he quickly realized what should be done, took the washing line and applied a tourniquet to Dima. My son was screaming in pain, but still behaved like a real man.

We were no longer dealing with a fictional text here, and Ukrainians would not be mistaken in reading this text as real-life account of the many atrocities happening daily in the civil war in the East of the country. So we hypothesized that this realistic text about death would act as MS to people living through the horrors of that war.

In the experiment, we employed the same pre- and post-questions and the same control text ('The History of the Toothbrush'). Yet no significant results were found for differences between experimental and control groups, or with respect to the control questions. A median split test revealed just 6 significant values below .05 (with one going against the prediction: the iPod theft question). Out of a total of 60 significance tests ( 6 pre-questions by 10 post-questions), this is really a negligible result.

An ANOVA test for the three text conditions (the Tolstoy text, 'The History of the Toothbrush' and the Donbass text) revealed not a single significant difference. 


\subsection{Study 5}

By using literary texts, the studies reported above used a methodology somewhat different from that used in earlier TMT studies. We were by now curious to see whether we could replicate these results - and also compare them to reactions to a literary text. To this end, in Study 5 we used the same Tolstoy text as had been used in Study 3, but now a considerably longer passage $(2,596$ words), so that reading it took approximately 15 minutes, matching the length of the other experimental condition: we requested half of the participants to write an essay about their own death. As an instruction, we used the very same wordings that are reported in several TMT studies: 'Please briefly describe the emotions that the thought of your own death arouses in you. Jot down, as specifically as you can, what you think will happen to you as you physically die and once you are physically dead'. To ensure the natural expression of thoughts, participants were invited to write the essay in their native language: Russian or Ukrainian.

We also considerably increased the number of preand post- variables. The 15 pre-test items were designed to measure participants' self-esteem, tolerance and openness ( 5 items per dimension), while the 30 post-test items assessed their openness to the issues of health, law, nationalism, outsiders, war / conflict, and tradition / religion (5 items per measure). The order of presentation of the items was mixed. 'Positively' and 'negatively' oriented scales were roughly of the same frequency.

Additionally, we included in the pre-test and the post-test two variables to check whether the MS enhances, as predicted by the theory (Becker, 1973: 17ff; Pyszczynski et al., 2002: 16), the view that humans and animals differ from each other more that that they resemble each other:

The boundary between humans and animals is not as great as most people think. What appears to be the result of complex thought and free will is really just the result of our biological programming and simple learning experiences.

Although we humans have some things in common with other animals, human beings are truly different. We are not simple creatures driven by our biological programming and learning experiences, but individuals with a will of our own, capable of making choices and creating our own destinies.

The experiment was run in Kiev in the fall of 2015 in small groups in a regular EFL classroom setting. Participants were again students of English at Borys Grinchenko Kyiv University (74\% female, mean age 18.7) - the sample comparable to those in Studies 1, 3 and 4 reported above. There were 27 participants for the essay condition, 31 for the Tolstoy text one, and 29 for the control group, which again read 'The History of the Toothbrush'. The experimenter (the second author of this article) reported that when looking through the essays the students wrote, one may be almost $100 \%$ sure that the task did generate MS. What the respondents wrote was very open and, in a sense, naïve, so it was obvious that the participants were really thinking about their own death at the moment of writing. It is remarkable that several students took the task so seriously that they refused to write the essay, as they found the idea itself appalling.

First, data reduction with a reliability analysis yielded only two dimensions with Cronbach's alpha high enough: self esteem (.66) and nationalism (.69). These two dimensions were created as new variables, and entered into a GLM analysis. No significant differences ensued. All individual items were also entered, but again without significant differences between the three experimental conditions. Figure 1 below illustrates the situation neatly.

\section{Means}
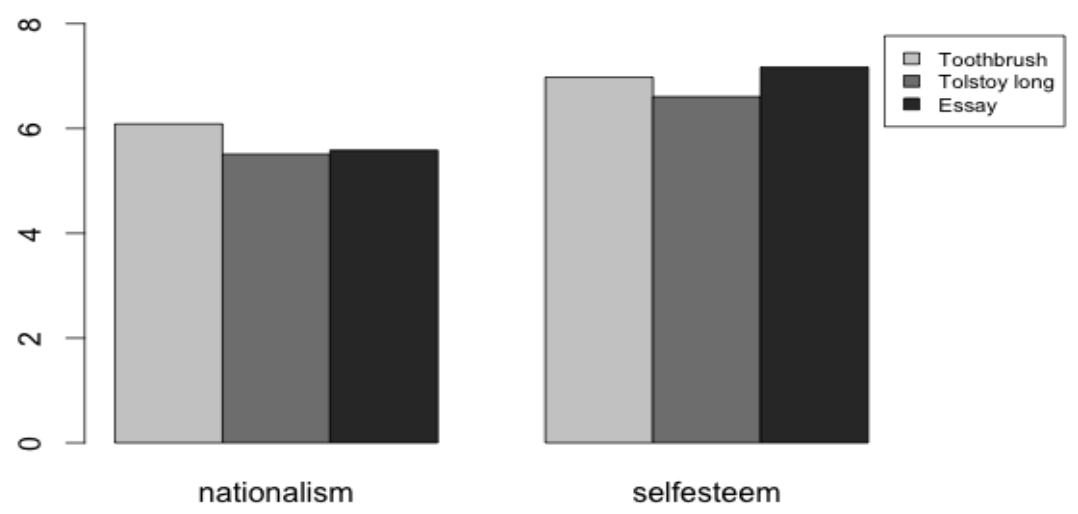

Fig. 1. Nationalistic and self-esteem feelings in the three conditions 
As can be seen, there is hardly any difference in response to items probing some form of nationalism and self-esteem after reading the Tolstoy text or writing the MS essay. And hardly any difference with the control group (whereby 'nationalism' was even slightly higher than in the experimental conditions!).

Since the reliability analysis revealed very low alpha's, we carried out a factor analysis (principal component analysis with orthogonal Varimax rotation). This yielded three factors with a total of $31.63 \%$ of variance explained. The first factor point toward strangeness, comprising items such as 'a student with tattoos' (rare in Ukraine), 'a foreigner sitting next to a vacant seat', 'a family from the Caucasus moving in as neighbours', etc. (variance explained $=13.69 \%$ ). The second factor clearly contains items to do with some form of nationalism: finding Ukraine a good country, a safe country, the opposite of a hopeless country, etc. (the variance explained by this factor runs to $10.58 \%$ ). The third factor we called safety. Items that load high on it are, for instance, 'defence against enemies', 'a strong army', 'preparation for war', etc.

A new variable for each of these factors was created. They were subsequently entered into a multivariate GLM, with self esteem as a covariate. No significant differences were found between the results of these three factors, split out according to the experimental conditions (the toothbrush text, the Tolstoy text, essay writing). Self esteem did not exert a significant influence.

\section{General results}

The series of experiments described before revealed no significant differences in response to the dependent variables between the experimental and control conditions. The mean response values were extremely close to each other for each of the texts read. We found some significant differences, but they are very limited: 2 highly significant results for the Tolstoy text, and 5 for the newspaper narratives, out of 60 significance tests in each case. We may thus assume that MS, as evoked by text content, does not operate in the way described by TMT so far.

One could argue that the methods employed to evoke MS, i.e., have participants read texts about death, differed from the by now classical method of having people write an essay about their emotional reactions to their own death. Therefore, it is all the more worrying that Study 5 could not replicate typical results of MS as reported by TMT, although in this case the methodology of essay writing, including the verbatim instruction used in TMT research, was employed. Finally, the typical mitigating factors (self esteem, openness, tolerance) that are reported in the literature as alleviating the effects of MS did not create a difference in response over the experimental conditions.

A possible explanation for the results could be a gender effect, as a considerable proportion of the participants in Ukraine were female. Ukraine itself is a female-oriented culture (see the work of Hofstede (2001); see also: https://geert-hofstede.com/ukraine.html; consulted 5 August 2016). Fear of death may be more male than female and more Western (and more materialist). As Arndt et al. (1997) write: 'men are often more overtly patriotic than women (...) whereas women tend to show more altruism and are more interested in establishing and maintaining reciprocal relationships' (309). And furthermore: 'in women, mortality salience failed to activate cognitions relevant to nationalism, but it did activate cognitions pertaining to romantic relationships' (313). This gender difference may be an explanation for the non-results that we obtained, and is certainly a matter to be further investigated in future research.

Age effect on the results could be another issue as we worked with predominantly one age group, largely in the range 18-25. The most thorough and most recent overview of potential explanatory factors in the empirical study of literature is no doubt Jacobs (2015).

A cultural effect is also a possibility. It could be that TMT does not work as usual in the two cultures (Ukraine and Germany), and cultural attitudes towards death are fundamentally different. There could be cultures in which thinking about death is not negative.

The null results could be alternatively explained by a non-effect of the dependent variables: possibly, the items used in the experiment did not really probe TMT. Or it could simply be the case that TMT makes no universal predictions and does not work with works of literature. All this comes amidst a plethora of studies demonstrating the highly limited replicability of psychological research. The journal Nature even speaks of a 'replication crisis' in psychology (Schooler, 2014; Achenbach, 2015; Baker, 2015; Ioannidis, 2015; Keener, 2015; Open Science Collaboration, 2015; Sample, 2015).

\section{Discussion}

So how to explain the fact that MS did not cause the typical results predicted by TMT when it was called on by reading literature?

Well, first there are different genre expectations - or cognitive sets - when people encounter literary texts. As Zwaan already convincingly showed in 1993, the same texts are read differently when readers believe they come from a literary novel or from a newspaper column: literary texts are read more slowly presumably demanding more attention: this seems to follow that reading them results in stronger memory of surface structure of the texts. They are also read with a weaker representation of referential information, plus a greater tolerance of ambiguity and contradictions.

But it is not only the reading strategies that are typical for literary reading: it is also the texts that differ. Ablali (2006) found, in a large corpus of literary and journal articles, published between 1980 and 2004, that literary texts generally contain longer words and longer sentences. 'The two genres also exhibited different morphosyntactic structures such as punctuation, use of the verbal tense, and pronouns, etc. (...). Also sentence length varies in literary texts, whereas it is rather uniform in newspaper texts' (Salgaro, 2015: 242), a result that is comparable to a similar analysis by Van Peer (1984). 
The theoretical position that is most outspoken in this respect is the theory on foregrounding; see Miall and Kuiken (1994), Van Peer (1986), Van Peer and Hakemulder (2006), Van Peer et al. (2007). Foregrounding is generally defined as:

(...) a form of textual patterning which is motivated specifically for literary-aesthetic purposes. (...) Foregrounding typically involves a stylistic distortion of some sort, either through an aspect of the text which deviates from a linguistic norm or, alternatively, where an aspect of the text is brought to the fore through repetition or parallelism (Simpson, 2014: 52).

In this sense literature builds a counter-reality toward everyday entrenched categories, which may explain why the usual mechanisms of TMT do not work when literary texts describe or evoke the experience of death. In a certain sense, however, this is strange, because several authors have convincingly shown that reading literature leads to transportation; see Appel et al. (2015), Green and Brock (2000), Hakemulder (2013). If, however, readers experience transportation or immersion in a story, then why are their reactions to MS not closer to those of real people investigated in TMT research? In the next paragraph we present a hypothesis to explain this remarkable fact.

In art theory, moreover, this phenomenon has been dealt with from the very beginning, for instance, in Aristotle's Poetics, under the label of catharsis ( $\kappa \alpha \dot{\theta} \theta \alpha \sigma \iota \varsigma)$, which explains that through Fear (phóbos) and Pity (éleos) the spectator (reader) experiences an (emotional) purification. While the Aristotelian notion of catharsis has been almost repudiated in the social sciences, from our perspective, MS in literature has as its effect not a defence mechanism, as predicted by TMT, but a psychological valve, that makes us accept our biological vulnerability. Following Freud (2013: 8):

[i]t is therefore inevitable that we should seek compensation for the loss of life in the world of fiction, in literature, and in the theatre. There we still find people who know how to die, who are even quite capable of killing others. There alone the condition for reconciling ourselves to death is fulfilled, namely, if beneath all the vicissitudes of life a permanent life still remains to us. It is really too sad that it may happen in life as in chess, where a false move can force us to lose the game, but with this difference, that we cannot begin a return match. In the realm of fiction, we find the many lives in one for which we crave. We die in identification with a certain hero and yet we outlive him and, quite unharmed, are prepared to die again with the next hero.

So if in everyday life people avoid MS, in fiction they look for it, which makes literature stand out of other MS triggers, and our findings throw a light upon the very special status that literature occupies in the minds of readers when it comes to MS. Certainly TMT researchers have not, so far, in the words of Willems and Jacobs (2016: 142) tapped in the potential of literature.
A range of research seems to underpin our hypothesis. Thus Koopman (2013) demonstrates how in part catharsis-like feelings play a role in the decision to read about a child's death (or the fear thereof). Beyond that, the author holds that the feeling of support in suffering and of seeking clarification 'for those who are grieving, reading about grief can help to put such personal experiences into perspective' (2013: 202). Koopman goes on saying that "'terror" does not appear crucial to gaining this type of insight' (2013: 203). The view is also corroborated by the research of Khoo and Oliver (2013). Similarly, Sopčak (2013), on the basis of two studies in which readers confronted their own finitude, comes to the conclusion that 'for some readers engagement with these texts not only moves them to the understanding of their own finitude, but also affords them an embodied experience of this finitude' (234).

In a more general sense, Anz (1998) discussed the delight readers may experience in reading about suffering, cruelty, aggression and death in literature. He also points to the efforts authors undertake to evoke genuine pain and harm in their art works. The hypothesis is that the delightful horror is a basic requirement in humans producing a sense of relief. Thus feeling about suffering in the field of arts is morally harmless. In the frame of fiction it induces pleasure, not anxiety about annihilation - and that is what Aristotle marked as the cathartic effect in his poetics.

All this then seems to clearly demonstrate that readers may actually seek MS in literature, and that its effect is not what TMT describes, as the theory does not seem to work with either fictional or real life texts.

\section{Prospects for future research}

As the participants of the studies described above were in their majority female, it would be interesting to run the experiment again with predominantly male participants to check whether gender is an issue in dealing with MS in literature.

Pyszczynski et al. (2002: 45) report an experiment where judges had to fix a bond in a hypothetical legal case. It could be reasonable to replicate this as a ceteris paribus experiment by changing the MS trigger. Instead of writing an essay about their own mortality, the experimental group should read some fictional texts about mortality as the priming stimulus.

The reported studies could also be replicated to probe whether the results would be the same or different across different demographic conditions. It still remains unclear whether teenagers, adolescents, middle aged groups and old aged people react differently.

The more outré and grotesque an incident is the more carefully it deserves to be examined, and the very point which appears to complicate a case is, when duly considered and scientifically handled, the one which is most likely to elucidate it (A. Conan Doyle. The Hound of the Baskervilles, 1981: 764). 


\section{Notes}

1 In this sense the term may be somewhat misleading. It does not solely refer to what most people might associate it with, i.e., terrorism, although that may fall under the definition, too. In TMT, 'terror' is a psychological consequence of the realization of one's eventual annihilation.

\section{REFERENCES}

1. Ablali, D. (2006). Écrire en critique: Exploration morpho-syntaxique sur corpus. Corpus en lettres et Sciences sociales: des documents numériques a l'interprétation. Actes du colloque internationald'Alibi, juillet 2006, C. Duteil \& B. Foulqué (Eds), (pp. 207-214). Paris: Texto [in French].

2. Achenbach, J. (2015). No, science's reproducibility problem is not limited to psychology. The Washington Post, 28 August. Retrieved from: https://www.washingtonpost.com/news/speaking-ofscience/wp/2015/08/28/no-sciences-reproducibilityproblem-is-not-limited-to-psychology .

3. Anz, T. (1998). Literatur und Lust: Glück und Unglück beim Lesen [Literature and Lust. Luck and bad luck in reading]. München: Beck [in German].

4. Appel, M., Gnambs, T., Richter, T. \& Green, M.C. (2015). The transportation scale - short form (TSSF). Media Psychology, 18(2), 231-257.

5. Arndt, J., Greenberg, J. \& Cook, A. (2002). Mortality salience and the spreading activation of worldview-relevant constructs: Exploring the cognitive architecture of terror management. Journal of Experimental Psychology, 131(3), 307-324.

6. Baker, M. (2015). Over half of psychology studies fail reproducibility test. Nature News, 27 August. Retrieved from: http://www.nature.com/news/over-halfof-psychology-studies-fail-reproducibility-test-1.18248 .

7. Becker, E. (1973). The denial of death. New York: Simon and Schuster.

8. Conan Doyl, A. (1981). The complete Sherlock Holmes. Harmondsworth: Penguin.

9. Freud, S. (2013). Reflections on war and death. Retrieved from: http://www.sophiaproject.org/uploads/1/3/9/5/13955288/freud_waranddeath.pdf.

10. Green, M.C. \& Brock, T.C. (2000). The role of transportation in the persuasiveness of public narratives. Journal of Personality and Social Psychology, 79(5), 701721, DOI: 10.1037/0022-3514.79.5.701.

11. Greenberg, J., Simon, L., Porteus, J., Pyszczynski, T. \& Solomon, S. (1995). Evidence of a terror management function of cultural icons: The effects of mortality salience on the inappropriate use of cherished cultural symbols. Personality and Social Psychology Bulletin, 21, 1221-1228.

12. Greenberg, J., Solomon, S. \& Pyszczynski, T. (1997). Terror management theory of self-esteem and social behavior: Empirical assessments and conceptual refinements. Advances in Experimental Social
2 This is one of the most extensive overviews of the research on TMT. Another excellent account is Greenberg et al. (1997).

3 We are grateful to Dr. Anna Rumbesht for collecting the data, and to Victor Chesnokov for advice on reading times.

4 This is the most recent and important article on foregrounding, raising fundamental questions.

Psychology, 29, M.P. Zanna (Ed), (pp. 61-139). New York: Academic Press.

13. Hakemulder, F. (2013). Travel experiences: A typology of transportation and other absorption states in relation to types of aesthetic response. Wie gebannt: Ästhetische Verfahren der affektiven Bildung von Aufmerksamkeit [As in a trance. Aesthetic methods in the affective training of affection]. J. Lüdtke et al. (Eds), (pp. 163-182).Berlin: Free University.

14. Hofstede, G. (2001). Culture's consequences: Comparing values, behaviors, institutions, and organizations across nations. Thousand Oaks, CA: Sage.

15. Ioannidis, J. (2015). Psychology experiments are failing the replication test - for good reason. The Guardian, 28 August. Retrieved from: http://www.theguardian.com/commentisfree/2015/aug/28/psyc hology-experiments-failing-replication-test-findings-science.

16. Jacobs, A. M. (2015). The scientific study of literary experience. Sampling the state of the art. Scientific Study of Literature, 5(2), 139-170.

17. Keener, A. B. (2015). Psychology's failure to replicate. The Scientist, 31 August. Retrieved from: http://www.the-

scientist.com/?articles.view/articleNo/43875/title/Psychol ogy-s-Failure-to-Replicate.

18. Khoo, G. S. \& Oliver, M. B. (2013). The therapeutic effects of narrative cinema through clarification. Reexamining catharsis. Scientific Study of Literature, 3(2), 266-293. DOI: 10.1075/ssol.3.2.06kho.

19. Kierkegaard, S. (1957). The concept of dread. Princeton: Princeton University Press [Original edition 1844].

20. Koopman, E. (2013). The attraction of tragic narrative. Catharsis and other motives. Scientific Study of Literature, 3(2), 178-208. DOI: 10.1075/ssol.3.2.03koo.

21. McGregor, H., Lieberman, J.D., Solomon, S., Greenberg, J., Arndt, J., Simon, L. \& Psyscinski, T. (1998). Terror management and aggression: Evidence that mortality salience motivates aggression against worldview threatening others. Journal of Personality and Social Psychology, 74, 590-605.

22. Miall, D. \& Kuiken, D. (1994). Foregrounding, defamiliarization and affect response to literary stories. Poetics, 22, 389-407.

23. Open Science Collaboration (2015) Estimating the reproducibility of psychological science. Science, 349 (6251). DOI: 10.1126/science.aac4716.

24. Pyszczynski, T., Wicklund, R.A., Floresky, S., Gauch, G., Koch, S., Solomon, S. \& Greenberg, J. (1996). 
Whistling in the dark: Exaggerated estimates of social consensus in response to incidental remainders of mortality. Psychological Science, 7, 332-336.

25. Pyszczynski, T., Solomon, S. \& Greenberg, J. (2002). In the wake of 9/11. The psychology of terror. Washington, DC: American Psychological Association.

26. Rosenblatt, A., Greenberg, J., Solomon, S., Pyszczynski, T. \& Lyon, D. (1989). Evidence for terror management theory: I. The effects of mortality salience on reactions to those who violate or uphold cultural values. Journal of Personality and Social Psychology, 57, 681-690.

27. Salgaro, M. (2015). How literary can literariness be? Methodological problems in the study of foregrounding. Scientific Study of Literature, 5(2), 229-249.

28. Sample, I. (2015). Study delivers bleak verdict on validity of psychology experiment results. The Guardian, 27 August. Retrieved from: http://www.theguardian.com/science/2015/aug/27/studydelivers-bleak-verdict-on-validity-of-psychologyexperiment-results.

29. Schimel, J., Simon, L., Greenberg, J., Pyszczynski, T., Solomon, S., Waxmonski, J. \& Arndt, J. (1999). Support for a functional perspective on stereotypes: Evidence that mortality salience enhances stereotypic thinking and preferences. Journal of Personality and Social Psychology, 77, 905-926.
30. Schooler, J.W. (2014). Metascience could rescue the 'replication crisis'. Nature 515, 9. DOI: 10.1038/515009a. Retrieved from: http://www.nature.com/news/metascience-could-rescuethe-replication-crisis-1.16275.

31. Simpson, P. (2014). Stylistics. A resource book for students. Second edition. New York: Routledge.

32. Sopčak, P. (2013). "He made her feel the beauty". Readers' responses to Maurice Blanchot and Virginia Woolf's treatments of finitude. Scientific Study of Literature, 3(2), 209-239. DOI: 10.1075/ssol.3.2.04sop.

33. Van Peer, W. (1984). Pulp and purpose. Stylistic analysis as an aid to a theory of texts. Dutch Quarterly Review, 14(3), 229-248.

34. Van Peer, W. (1986). Stylistics and psychology. Investigations of foregrounding. London: Croom Helm.

35. Van Peer, W. \& Hakemulder, F. (2006). Foregrounding. Encyclopaedia of language and linguistics. K. Brown (Ed), (pp. 546-551). Oxford: Elsevier.

36. Van Peer, W., Hakemulder, J. \& Zyngier, S. (2007). Lines on feeling: Foregrounding, aesthetics and meaning. Language and Literature, 16(2), 197-213.

37. Willems, R. \& Jacobs, A. (2016). Caring about Dostoyevsky: The untapped potential of studying literature. Trends in Cognitive Sciences, 20, 243-245.

38. Zwaan, R. (1993). Aspects of literary comprehension. Philadelphia: John Benjamins.

Віллі ван Пір, доктор наук, професор, Університет Людвіга Максиміліана,

Профессор-Хубер Плати, 2, м. Мюнхен, Німеччина,

Ганна Вадимівна Чеснокова, кандидат філологічних наук, професор, Київський університет імені Бориса Грінченка, вул. Бульварно-Кудрявська, 18/2, м. Київ, Україна,

Mammiac Unрінгер,

доктор наук, Університет Людвіга Максиміліана, Профессор-Хубер Плати, 2, м. Мюнхен, Німеччина

\section{ТРАГІЧНА ЕМПАТІЯ У ЧИТАННІ ХУДОЖНЬОГО ТЕКСТУ: ПРИКЛАД ТЕОРІЇ КЕРУВАННЯ СТРАХОМ СМЕРТІ?}

Статтю присвячено вивченню ступеня придатності висновків теорії керування страхом смерті до читання художнього тексту. Насправді, у літературі опис смерті є непоодиноким, але чи викликає читання про смерть ті ж самі реакції, про які постулюється у теорії керування страхом смерті? Щоб отримати відповідь на таке запитання, авторами було проведено п’ять експериментів, у яких перевірялася гіпотеза, розроблена у межах теорії керування страхом смерті, про те, що безпосереднє зіткнення зі смертністю підсилює упередженість по відношенню до чужинців і підвищує внутрішньогрупові цінності. На відміну від наших очікувань, результати експериментів не підтвердили таке припущення, і це ставить під сумнів гіпотезу про трагічну емпатію. Постає питання про те, чи відрізняється усвідомлення власної смертності, яке викликає художня література, від інших випадків зіткнення зі смертю, і це порушує питання, чому читачі прагнуть зануритися у настільки трагічні емоції. Автори статті роблять припущення про те, що зіткнення зі смертю у художньому тексті може зменшити психологічне напруження, яке зазвичай викликають інші нагадування про смерть, і така перспектива може бути пов'язана з аристотелівським поняттям катарсису.

Ключові слова: емпатія, теорія керування страхом смерті, усвідомлення смертності, художній текст, нехудожній текст, катарсис.

Submitted on January, 16, 2017 